\title{
Influence of Peach (Prunus persica L. Batsch) Fruit Addition on Quality Characteristics and Antioxidant Activities of Beer
}

\author{
Kyung-Mi Jung ${ }^{1}$, San-Yeong Kim¹, Eun-Chul Seo¹, Hyung-III \\ Lee ${ }^{1}$, Oh-Heun Kwon ${ }^{1}$, Hye-Ryun Kim², Sanjeev Kumar Dhungana ${ }^{3}$, \\ Yong-Sung Park ${ }^{3}$, II-Doo Kim ${ }^{4}$
}

\author{
${ }^{1}$ Cheongdo Peach Research Institute, GyeongSangBuk-Do Agricultural Technology Administration, Cheongdo \\ 38315, Korea \\ ${ }^{2}$ Cheonnyeonmiin Co. Ltd., Gyeongju-si 38180, Korea \\ ${ }^{3}$ School of Applied Biosciences, Kyungpook National University, Daegu 41566, Korea \\ ${ }^{4}$ International Institute of Agricultural Research and Development, Kyungpook National University, Daegu 41566, \\ Korea
}

\begin{abstract}
Many studies have been carried out to enhance the quality characteristics of beer, one of the most famous alcoholic beverages in the world. Objective of the present study was to investigate the quality characteristics and antioxidant potential of beer after addition of peach fruits of two cultivars, Cheonhong and Kanoiwa Hakuto. Chemical characteristics such as $\mathrm{pH}$, titratable acidity and alcohol concentration; color values; 1,1-diphenly-2picrylhydrazyl (DPPH) radical scavenging activities; total phenolic contents and sensory characteristics of different beer samples were evaluated. The $\mathrm{pH}$ value of the control sample $(4.09)$ was significantly $(\mathrm{p}<0.05)$ higher than those of the peach beer samples which ranged from 3.81 to 4.00. The alcohol concentration and DPPH radical scavenging potential of peach beer were not significantly $(\mathrm{p}>0.05)$ influenced by the addition of the fruits compared to the control sample (4.0\%). The total phenolic content and overall acceptability of most of the beer samples were significantly $(p<0.05)$ increased with the addition of the fruits. The results of the present study suggested that quality characteristics and total phenolic content of beer can be enhanced by addition of peach fruits.
\end{abstract}

Keywords: Antioxidant Potential, Beer, Overall Acceptance, Peach Fruit

\begin{abstract}
Introduction
Beer is one of the most widely consumed alcoholic beverages around the world (Amienyo and Azapagic, 2016). Although it is one of the oldest beverages, the basic ingredients of beer water, malt or grains, hops and yeasts, and production methods have not been much changed over centuries (Ambrosi et al., 2014; Pires and Brányik, 2015). The starch source such as barley and wheat malts and other grains in a beer preparation provides the fermentable material and is an important determinant of beer strength. The gluten content, especially in the grains from which most beer varieties are prepared, makes the beer inappropriate for coeliac disease patients to consume (Hager et al., 2014) although beer consumption is considered good for health under certain conditions (de Gaetano et al., 2016).
\end{abstract}

Various fruits have been used as beer adjunct or flavoring agent for a long time. Fresh fruits such as cherries and raspberries are mixed to the finished beer and allowed for additional fermentation to produce a special fruit beer in Belgium (Jackson, 1994; De Keersmaecker, 1996). The fruits may be added only for flavoring the finished beer products in the modern breweries. A Belgian fruit beer called Fruli is prepared with $70 \%$ of wheat beer and $30 \%$ of fruit juice (Fedora and Fedora, 2014).

Peach is considered as an economically important fruit crop and also recommended for its various health benefits (Manzoor et al., 2012; Yang et al., 2011). Peach also contains caffeoylquinic acid, a bioactive polyphenol with high antioxidant activity and beneficial effect in human health (Luo et al., 2008). Consumption of peach also provides a potential protection against various chronic diseases by scavenging the reactive oxygen species in human

This article is published under the terms of the Creative Commons Attribution License 4.0

Author(s) retain the copyright of this article. Publication rights with Alkhaer Publications.

Published at: http://www.ijsciences.com/pub/issue/2017-08/

DOI: 10.18483/ijSci.1411; Online ISSN: 2305-3925; Print ISSN: 2410-4477 

of Beer

blood plasma with the antioxidants present in the fruit (Tsantili et al., 2010). The fruits also contain polyamines, $\gamma$-aminobutyric acid (GABA), and proline (Cao et al., 2016). GABA is an important amino acid as it is related to learning and memory, stroke and neurodegenerative diseases; relieving anxiety, sedation, anticonvulsant, and muscle relaxation functions (Krogsgaard-Larsen, 1989; Mody et al., 1994; Oh and Oh, 2004). GABA also is also related to bioactive functions such as regulating blood cholesterol, suppressing blood pressure, improving cerebral blood flow, reducing insomnia, depression, and pain (Dhakal et al., 2012). It is also reported to have anti-diabetic effect (Nikmaram et al., 2017). Proline was found to lead to the formation of fusel alcohols, and therefore impact beer's aroma, flavor and overall alcohol content (Procopio et al., 2013).

Peaches have been cultivated in Korea from ancient times. They are considered as the fruit of happiness, riches, honors and longevity. Since peach is a delicious fruit containing different nutrients and phytochemicals, the objective of the present study was to investigate the quality characteristics and antioxidant potentials of beer prepared by addition of peach.

\section{Materials and Methods}

\section{Chemicals and materials}

Beer mix (Great American Beverage Company, Reno, NV, USA) was purchased from a local store in Daegu, Korea. Fruits of two cultivars of peach (Prunus persica L. Batsch) Cheonhong and Kanoiwa Hakuto, grown at Cheongdo Peach Experiment Station, Gyeongsangbuk-do, Korea were harvested at commercial maturity stage and used in this study. There was no specific reason to consider the two cultivars in the present study. All the chemicals and reagents of analytical grades were used in the present study.

\section{Preparation of beer}

Peach beer was prepared as described by Cho et al. (2015). A commercial beer mix (0.9 kg: powdered dry malted barley extract, hop extract), yeast $(2.5 \mathrm{~g})$, water $(10 \mathrm{~L})$, and different proportions of ripe peach were mixed and kept for fermentation $\left(25^{\circ} \mathrm{C}, 6 \mathrm{~d}\right)$, transferred to low temperature storage $\left(4^{\circ} \mathrm{C}, 3 \mathrm{~d}\right)$, subjected to second-stage fermentation $\left(25^{\circ} \mathrm{C}, 7 \mathrm{~d}\right)$ with $5 \mathrm{~g}$ of added sugar per liter of fermenting product, followed by second-stage low temperature storage $\left(4^{\circ} \mathrm{C}, 3 \mathrm{~d}\right)$. After preparation, beer varieties were stored at $4^{\circ} \mathrm{C}$ for subsequent analyses. Different persimmon beer were named as OB-0: ordinary beer containing no added peach, $\mathrm{CH}-300$ : peach beer containing $300 \mathrm{~g}$ of peach, Cheonhong for $10 \mathrm{~L}$ of water, CH-500: peach beer containing $500 \mathrm{~g}$ of peach, Cheonhong for $10 \mathrm{~L}$ of water, $\mathrm{CH}-800$ : peach beer containing $800 \mathrm{~g}$ of peach, Cheonhong for $10 \mathrm{~L}$ of water, $\mathrm{KH}-300$ : peach beer containing $300 \mathrm{~g}$ of peach, Kanoiwa Hakuto for $10 \mathrm{~L}$ of water, KH-500: peach beer containing $500 \mathrm{~g}$ of peach, Kanoiwa Hakuto for $10 \mathrm{~L}$ of water, KH-800: peach beer containing $800 \mathrm{~g}$ of peach, Kanoiwa Hakuto for $10 \mathrm{~L}$ of water. A range of different amounts of peach fruits was applied in the present study so that optimum quantity of peach could be determined for superior quality peach beer.

\section{Chemical characteristics}

The $\mathrm{pH}$ values of beer samples were determined using a pH Meter (Model 250, Beckman Coulter Inc., Fullerton, CA, USA). Titratable acidity (as lactic acid $\mathrm{g} / \mathrm{L}$ ) was measured by adding $5 \mathrm{~mL}$ of peach beer to $125 \mathrm{~mL}$ of deionized water and titrating with $0.1 \mathrm{~N}$ sodium hydroxide to an endpoint $\mathrm{pH}$ 8.2. Concentration of alcohol was measured as described by Ough and Amerine (1988). All chemical measurements were replicated three times and the average values were reported.

\section{Color measurement}

$\mathrm{L}^{*}$ (lightness), a* (redness, + or greenness, -), b* (yellowness, + or blueness, - ) values of beer were determined using a chromameter (CR-300 Minolta Chromameter, Minolta Corp., Tokyo, Japan). The instrument was standardized with D65 illuminant using A Minolta calibration plate (YCIE $=94.5$, $\mathrm{XCIE}=0.3160, \quad \mathrm{YCIE}=0.330)$ and a HunterLab standard plate $\left(\mathrm{L}^{*}=97.51, \mathrm{a}^{*}=-0.18, \mathrm{~b}^{*}=+1.67\right)$ (Kim et al., 2015). Color values were measured on three zones of peach beer and the averages were calculated.

\section{Total phenolic content}

The total phenolic content of beer samples was estimated according to the Folin-Ciocalteau method (Singleton, 1999) with some modifications. Fifty microliters of peach beer and $1000 \mu \mathrm{L}$ of $2 \%(\mathrm{w} / \mathrm{v})$ aqueous $\mathrm{Na}_{2} \mathrm{CO}_{3}$ were mixed, vortex and kept for 3 min. Fifty microliters of $1 \mathrm{~N}$ Folin reagent was added to the mixture and incubated at room temperature in dark for $30 \mathrm{~min}$. The absorbance value of the mixture was measured at $750 \mathrm{~nm}$ using a microplate spectrophotometer (Multiskan GO, Thermo Fisher Scientific, Oy, Vantaa, Finland). Total phenolic content was determined as gallic acid equivalents $(\mu \mathrm{g}$ $\mathrm{GAE} / \mathrm{mL}$ ), and average values of three measurements were reported.

\section{DPPH radical scavenging activity}

The 1,1-diphenly-2-picrylhydrazyl (DPPH) radical scavenging activity was determined as described by Cheung et al. (2003) with some modifications. One hundred microliters of $0.1 \%$ (w/v) DPPH-methanol solution was mixed with $0.1 \mathrm{~mL}$ of sample. The 

of Beer

mixture was left to allow reaction at room temperature in dark for $30 \mathrm{~min}$ and the absorbance of the reaction mixtures was measured at $517 \mathrm{~nm}$ using a microplate spectrophotometer (Multiskan GO). The radical-scavenging activity (RSA) was calculated as a percentage inhibition using an equation

$\% \mathrm{RSA}=\left(1-\mathrm{S}_{\mathrm{ab}} / \mathrm{C}_{\mathrm{ab}}\right) \times 100$

where, $S_{a b}$ is the absorbance of the sample and DPPH solution; $\mathrm{C}_{\mathrm{ab}}$ is absorbance of DPPH solution without sample. The assays were carried out in triplicate and the results are expressed as average values.

\section{Sensory property evaluation}

Freshly prepared beer samples were considered for the sensory property evaluation. Beer samples prepared with different proportions of peach were evaluated for color, flavor and overall acceptance based on the scales: $1=$ very poor, $2=$ poor, $3=$ moderate, $4=$ good, $5=$ very good. All the sensory properties were evaluated by 20 volunteer panelists (10 women and $10 \mathrm{men}$ ). The volunteer panelists were selected from the list of graduate students of College of Agriculture and Life Sciences, Kyungpook National University, Daegu, Korea (Kim et al., 2015). The results presented are the average values of 20 evaluations for each sensory property.

\section{Statistical analysis}

Data were subjected to analysis of variance using
SAS 9.4 (SAS Institute Inc., Cary, NC, USA) and differences between sample means were determined with Tukey test at 5\% probability level. Average values of three replications were reported unless otherwise mentioned.

\section{Results and Discussion}

\section{Chemical characteristics of peach beer}

The chemical compositions of different peach beer samples are shown in Table 1 . The $\mathrm{pH}$ value of OB-0 (4.09) was significantly $(\mathrm{p}<0.05)$ higher than those of the other peach beer which ranged from 3.81 to 4.00. The reduced $\mathrm{pH}$ value of peach beer samples might be due to the addition of peaches which generally have lower $\mathrm{pH}$ value (Samara et al., 2017) than that of OB-0 (4.09). Concentration of alcohol is an important factor of any alcoholic beverages including beer. The alcohol concentrations of peach beer samples were not significantly $(p>0.05)$ altered with the addition of peach fruits compared to the control sample (OB-0). The results agree with those of Cho et al. (2015) who applied persimmon fruits to prepare beer. The TA (titratable acidity) values of peach beer samples were significantly $(\mathrm{p}<0.05)$ higher $(0.32$ $0.54 \mathrm{~g} / 100 \mathrm{~mL}$ of lactic acid) than the control sample $(0.12 \mathrm{~g} / 100 \mathrm{~mL}$ of lactic acid). The difference in TA values occurred among peach beer samples might be due to addition of peaches.

Table 1. Chemical characteristics of peach beer

\begin{tabular}{|c|c|c|c|}
\hline \multirow{2}{*}{ Sample ${ }^{1)}$} & \multicolumn{3}{|c|}{ Parameter } \\
\hline & $\mathrm{pH}$ & Alcohol $(\%, \mathrm{v} / \mathrm{v})$ & Titratable acidity $^{2)}(\mathrm{g} / 100 \mathrm{~mL})$ \\
\hline OB-0 & $4.09 \pm 0.03^{\mathrm{a} 3)}$ & $4.0 \pm 0.02^{\mathrm{a}}$ & $0.12 \pm 0.02^{\mathrm{f}}$ \\
\hline $\mathrm{CH}-300$ & $4.00 \pm 0.02^{\mathrm{b}}$ & $4.0 \pm 0.03^{\mathrm{a}}$ & $0.32 \pm 0.01^{\mathrm{e}}$ \\
\hline $\mathrm{CH}-500$ & $3.97 \pm 0.01^{\mathrm{bc}}$ & $4.0 \pm 0.05^{\mathrm{a}}$ & $0.40 \pm 0.01^{\mathrm{c}}$ \\
\hline $\mathrm{CH}-800$ & $3.94 \pm 0.02^{\mathrm{c}}$ & $4.0 \pm 0.03^{\mathrm{a}}$ & $0.54 \pm 0.02^{\mathrm{a}}$ \\
\hline KH-300 & $4.01 \pm 0.03^{\mathrm{b}}$ & $4.0 \pm 0.01^{\mathrm{a}}$ & $0.35 \pm 0.03^{\mathrm{d}}$ \\
\hline KH-500 & $3.91 \pm 0.03^{\mathrm{c}}$ & $4.0 \pm 0.03^{\mathrm{a}}$ & $0.41 \pm 0.02^{\mathrm{c}}$ \\
\hline KH-800 & $3.81 \pm 0.01^{\mathrm{d}}$ & $4.0 \pm 0.02^{\mathrm{a}}$ & $0.48 \pm 0.01^{\mathrm{b}}$ \\
\hline
\end{tabular}

\footnotetext{
${ }^{1)}$ OB-0: ordinary beer containing no added peach, $\mathrm{CH}-300$ : peach beer containing $300 \mathrm{~g}$ of peach, Cheonhong for 10 L of water, CH-500: peach beer containing $500 \mathrm{~g}$ of peach, Cheonhong for $10 \mathrm{~L}$ of water, $\mathrm{CH}-800$ : peach beer containing $800 \mathrm{~g}$ of peach, Cheonhong for $10 \mathrm{~L}$ of water, KH-300: peach beer containing $300 \mathrm{~g}$ of peach, Kanoiwa Hakuto for $10 \mathrm{~L}$ of water, KH-500: peach beer containing $500 \mathrm{~g}$ of peach, Kanoiwa Hakuto for $10 \mathrm{~L}$ of water, KH800: peach beer containing $800 \mathrm{~g}$ of peach, Kanoiwa Hakuto for $10 \mathrm{~L}$ of water..

${ }^{2)}$ Expressed as anhydrous lactic acid.

${ }^{3)}$ Quoted values are means \pm standard deviations of triplicate measurements. The values followed by different superscripts in the same column are significantly different $(\mathrm{p}<0.05)$.
}

Color value of peach beer

Hunter's color values ( $\mathrm{L}^{*}, \mathrm{a}^{*}$ and $\mathrm{b}^{*}$ values) of beer samples are shown in Table 2. The $\mathrm{L}^{*}$ (lightness) values of peach beer ranged from 58.15 to 66.06, which was significantly $(\mathrm{p}<0.05)$ lower than that of OB-0 (control) beer (86.11). The $\mathrm{a}^{*}$ (redness) values 

of Beer

of peach beer samples $(-1.60$ to -0.02$)$ were significantly $(\mathrm{p}<0.05)$ lower than that of the control sample (0.31). The yellowness values of OB-0 (23.11) was significantly $(\mathrm{p}<0.05)$ higher than those of the peach beer samples (4.22-18.98). These results indicate that the variations in $\mathrm{L}^{*}$ (lightness), $\mathrm{a}^{*}$ (redness) and $b^{*}$ (yellowness) values among beer samples might to due to addition of various proportions of different peach cultivars.

Table 2. Hunter's color values of peach beer

\begin{tabular}{lccc}
\hline & & \multicolumn{3}{c}{ Color value $^{2)}$} \\
\cline { 2 - 4 } Sample $^{1)}$ & $\mathrm{L}^{*}$ (lightness) & $\mathrm{a}^{*}$ (redness) & $\mathrm{b}^{*}$ (yellowness) \\
\hline OB-0 & $86.11 \pm 0.08^{\mathrm{a} 3)}$ & $0.31 \pm 0.06^{\mathrm{a}}$ & $23.11 \pm 0.22^{\mathrm{a}}$ \\
CH-300 & $58.15 \pm 0.07^{\mathrm{f}}$ & $-0.82 \pm 0.09^{\mathrm{e}}$ & $15.95 \pm 0.06^{\mathrm{e}}$ \\
CH-500 & $62.31 \pm 0.10^{\mathrm{c}}$ & $-0.70 \pm 0.03^{\mathrm{d}}$ & $18.98 \pm 0.09^{\mathrm{c}}$ \\
CH-800 & $61.32 \pm 0.17^{\mathrm{d}}$ & $-0.02 \pm 0.01^{\mathrm{b}}$ & $4.22 \pm 0.22^{\mathrm{g}}$ \\
KH-300 & $65.96 \pm 0.08^{\mathrm{b}}$ & $-1.58 \pm 0.03^{\mathrm{f}}$ & $18.12 \pm 0.47^{\mathrm{d}}$ \\
KH-500 & $66.06 \pm 0.25^{\mathrm{b}}$ & $-1.60 \pm 0.01^{\mathrm{f}}$ & $20.21 \pm 0.24^{\mathrm{b}}$ \\
KH-800 & $60.64 \pm 0.13^{\mathrm{e}}$ & $-0.48 \pm 0.01^{\mathrm{c}}$ & $5.88 \pm 0.28^{\mathrm{f}}$
\end{tabular}

${ }^{1)}$ Samples are defined in Table 1.

${ }^{2)}$ L: lightness (100, white; 0, black), a: redness (-, green; +, red), b: yellowness (-, blue; +, yellow).

${ }^{3)}$ Quoted values are means \pm standard deviations of triplicate measurements. The values followed by different superscripts in the same column are significantly different $(\mathrm{p}<0.05)$.

DPPH radical scavenging activity and total phenolic content

The DPPH radical scavenging activities were not significantly $(\mathrm{p}>0.05)$ different whereas the total phenolic contents were significantly $(p<0.05)$ different among beer samples (Table 3). The total phenolic contents of peach beer samples (513.15$618.45 \mathrm{mg} \mathrm{GAE} / \mathrm{mL})$ were significantly $(\mathrm{p}<0.05)$ higher than those of the control, OB-0 $(500.43 \mathrm{mg}$
$\mathrm{GAE} / \mathrm{mL}$ ). High total phenolic content was found for KH-500 sample as compared to the others. Phenolic compounds like polyphenols, flavonoids and flavonols in alcoholic beverage are considered as important constituents as they are accounted for antioxidant activities (Park and Lee, 2002). Therefore, it is apparent that addition of peach greatly enhance the total phenolic contents of beer.

Table 3. DPPH radical scavenging activities and total phenols content of peach beer

\begin{tabular}{ccc}
\hline Sample $^{1)}$ & $\begin{array}{c}\text { DPPH } \\
\text { (\% Inhibition })\end{array}$ & $\begin{array}{c}\text { Total phenols content } \\
(\mu \mathrm{g} \mathrm{GAE} / \mathrm{mL} \text { of sample })\end{array}$ \\
\hline OB-0 & $86.11 \pm 1.31^{\mathrm{a})}$ & $500.43 \pm 4.11^{\mathrm{e}}$ \\
CH-300 & $88.33 \pm 1.00^{\mathrm{a}}$ & $576.45 \pm 3.17^{\mathrm{c}}$ \\
CH-500 & $88.59 \pm 1.21^{\mathrm{a}}$ & $577.71 \pm 2.92^{\mathrm{c}}$ \\
CH-800 & $86.98 \pm 1.08^{\mathrm{a}}$ & $506.74 \pm 3.11^{\mathrm{e}}$ \\
KH-300 & $88.54 \pm 1.35^{\mathrm{a}}$ & $610.79 \pm 1.71^{\mathrm{b}}$ \\
KH-500 & $88.90 \pm 1.33^{\mathrm{a}}$ & $618.45 \pm 2.00^{\mathrm{a}}$ \\
KH-800 & $87.53 \pm 1.25^{\mathrm{a}}$ & $513.15 \pm 3.66^{\mathrm{d}}$ \\
\hline
\end{tabular}

\footnotetext{
${ }^{1)}$ Samples are defined in Table 1.

${ }^{2)}$ Gallic acid equivalent.

${ }^{3)}$ Quoted values are means \pm standard deviations of triplicate measurements. The values followed by different superscripts in the same column are significantly different $(\mathrm{p}<0.05)$.
} 

of Beer

\section{Sensory evaluation of peach beer}

Sensory evaluation is a useful parameter to evaluate the human perception of flavor attributes (Jabalpurwala et al., 2009). The sensory evaluation scores for different beer samples are shown in Table 4. The color acceptability of OB-0 (4.25 color value) scored significantly higher $(\mathrm{p}<0.05)$ than all the peach beer samples $(3.00-3.41$ color value).
However, the flavor and overall acceptability scores of peach beer samples, except $\mathrm{CH}-300$ and $\mathrm{KH}-300$, were significantly $(p<0.05)$ higher than that of the OB-0 (3.66 and 3.75, respectively). The variation in the perception of oral sensations can be influenced by various factors including gender, age, health/medication, physiological factor etc. (Mojet et al., 2003; Schiffman, 2007).

Table 4. Sensory evaluation scores for peach beer

\begin{tabular}{lccc}
\hline & \multicolumn{3}{c}{ Sensory evaluation acceptability } \\
Sample $^{1)}$ & Color & Flavor & Overall acceptance \\
\cline { 2 - 3 } OB-0 & $4.25 \pm 0.11^{\mathrm{a} 2)}$ & $3.66 \pm 0.19^{\mathrm{c}}$ & $3.75 \pm 0.09^{\mathrm{c}}$ \\
CH-300 & $3.41 \pm 0.20^{\mathrm{b}}$ & $3.58 \pm 0.22^{\mathrm{c}}$ & $3.89 \pm 0.15^{\mathrm{b}}$ \\
$\mathrm{CH}-500$ & $3.20 \pm 0.06^{\mathrm{b}}$ & $3.98 \pm 0.15^{\mathrm{b}}$ & $3.98 \pm 0.05^{\mathrm{b}}$ \\
CH-800 & $3.00 \pm 0.07^{\mathrm{c}}$ & $4.31 \pm 0.08^{\mathrm{a}}$ & $4.20 \pm 0.09^{\mathrm{a}}$ \\
KH-300 & $3.33 \pm 0.12^{\mathrm{b}}$ & $3.62 \pm 0.20^{\mathrm{c}}$ & $4.00 \pm 0.13^{\mathrm{b}}$ \\
KH-500 & $3.25 \pm .0 .15^{\mathrm{b}}$ & $3.99 \pm 0.15^{\mathrm{b}}$ & $4.05 \pm 0.11^{\mathrm{b}}$ \\
KH-800 & $3.11 \pm 0.16^{\mathrm{c}}$ & $4.44 \pm 0.16^{\mathrm{a}}$ & $4.23 \pm 0.10^{\mathrm{a}}$ \\
\hline
\end{tabular}

${ }^{\text {T) }}$ Samples are defined in Table 1.

${ }^{2)}$ Quoted values are means \pm standard deviations of triplicate experiments $(n=20)$ based on 5-point scores (very poor, 1; poor, 2; moderate, 3; good, 4; very good, 5). The values followed by different superscripts in the same column are significantly different $(\mathrm{p}<0.05)$.

In conclusion, addition of peach fruits improved the quality of beer. The addition of $500 \mathrm{~g}$ of the fruits of both cultivars increased the phenolic contents to the highest value, however, the highest overall acceptance value was scored for $500 \mathrm{~g}$ per $10 \mathrm{~L}$ of water containing raw fermenting materials. Based on the overall acceptability score, it can be suggested that the optimum proportion of peach fruits to be added to the beer is $500 \mathrm{~g}$ per $10 \mathrm{~L}$ of water containing raw fermenting materials.

\section{Conflict of Interest}

The authors declare no conflict of interest.

\section{References}

1. Ambrosi A, Cardozo NSM, Tessaro IC. (2014). Membrane separation processes for the beer industry: A review and state of the art. Food bioprocess tech., 7: 921-936. http://dx.doi.org/10.1007/s11947-014-1275-0

2. Amienyo D, Azapagic A. (2016). Life cycle environmental impacts and costs of beer production and consumption in the uk. Int. J. Life Cycle Assess., 21: 492-509. http://dx.doi.org/10.1007/s11367-016-1028-6

3. Cao S, Song C, Shao J, Bian K, Chen W, Yang Z. (2016). Exogenous melatonin treatment increases chilling tolerance and induces defense response in harvested peach fruit during cold storage. J. Agr. Food Chem., 64: 5215-22. http://dx.doi.org/10.1021/acs.jafc.6b01118

4. Cheung LM, Cheung PCK, Ooi VEC. (2003). Antioxidant activity and total phenolics of edible mushroom extracts. Food Chem., 81: 249-255. http://dx.doi.org/10.1016/S03088146(02)00419-3

5. Cho J-H, Cho M-G, Cho D-H, Kim I-D, Dhungana SK, Shin D-H. (2015). Addition of ripe persimmon enhanced the antioxidant potential and quality characteristics of persimmon beer. Fruit Sci. Technol. Kor., 1: 6-10.

6. de Gaetano G, Costanzo S, Di Castelnuovo A, Badimon L, Bejko D, Alkerwi A, Chiva-Blanch G, Estruch R, La Vecchia C, Panico S, Pounis G, Sofi F, Stranges S, Trevisan M, Ursini F, Cerletti C, Donati MB, Iacoviello L. (2016). Effects of moderate beer consumption on health and disease: A consensus document. Nutr. Metab. Cardiovasc. Dis. $\quad 26$ : 443-467. http://dx.doi.org/10.1016/j.numecd.2016.03.007

7. De Keersmaecker J. (1996). The mystery of lambic beer. Sci. Am., 275: 74-80.

8. Dhakal R, Bajpai VK, Baek KH. (2012). Production of gaba $(\gamma$-aminobutyric acid) by microorganisms: A review. Braz. J. Microbiol., 43: 1230-1241. http://dx.doi.org/10.1590/S151783822012000400001

9. Fedora B, Fedora L. (2014). The foodie's beer book: The art of pairing and cooking with beer for any occasion. Skyhorse Publishing, Inc., New York.

10. Hager AS, Taylor JP, Waters DM, Arendt EK. (2014). Gluten free beer-A review. Trends Food Sci. Technol., 36: 44-54. https://doi.org/10.1016/j.tifs.2014.01.001

11. Jabalpurwala FA, Smoot JM, Rouseff RL. (2009). A comparison of Citrus blossom volatiles. Phytochemistry, 70 (11-12), http://dx.doi.org/10.1016/j.phytochem.2009.07.031

12. Jackson M. (1994). Michael Jackson's Beer Companion, Duncan Baird Publishers, London.

13. Kim MO, Kim ID, Dhungana SK, Lee JW, Shin DH (2015). Influence of blueberry and black rice powders on quality characteristics of the korean traditional rice wine takju. Food Sci. Biotechnol., 24: 439-444. http://dx.doi.org/10.1007/s10068-015-0058-3.

14. Krogsgaard-Larsen P. (1989). Gaba receptors. Receptor pharmacology and function, 349-383.

15. Luo J, Butelli E, Hill L, Parr A, Niggeweg R, Bailey P, Weisshaar B, Martin C. (2008). Atmyb12 regulates caffeoyl quinic acid and flavonol synthesis in tomato: Expression in fruit results in very high levels of both types of polyphenol. 
Plant J., 56: 316-326. http://dx.doi.org/10.1111/j.1365313X.2008.03597.X

16. Manzoor M, Anwar F, Mahmood Z, Rashid U, Ashraf M. (2012). Variation in minerals, phenolics and antioxidant activity of peel and pulp of different varieties of peach (prunus persica 1.) fruit from pakistan. Molecules, 17: 64916506. http://dx.doi.org/10.3390/molecules17066507

17. Mody I, De Koninck Y, Otis TS, Soltesz I. (1994). Bridging the cleft at gaba synapses in the brain. Trends Neurosci., 17 : 517-525. http://dx.doi.org/10.1016/0166-2236(94)90155-4

18. Mojet J, Christ-Hazelhof E, Heidema J. (2001). Taste perception with age: Generic or specific losses in threshold sensitivity to the five basic tastes? Chem. Senses, 26: 845860.

19. Nikmaram N, Dar BN, Roohinejad S, Koubaa M, Barba FJ, Greiner R, Johnson SK. (2017). Recent advances in $\gamma$ aminobutyric acid (gaba) properties in pulses: An overview. J. Sci. Food Agric., 97: 2681-2689. http://dx.doi.org/10.1002/jsfa.8283

20. Oh $\mathrm{CH}$, Oh SH. (2004). Effects of germinated brown rice extracts with enhanced levels of gaba on cancer cell proliferation and apoptosis. J. Med. Food, 7: 19-23. http://dx.doi.org/10.1089/109662004322984653

21. Ough CS, Amerine MA. (1988). Methods for analysis of musts and wines. 2nd ed. John Wiley and Sons, New York

22. Park C-S, Lee T-S. (2002). Quality characteristics of takju prepared by wheat flour nuruks. Korean J. Food Sci. Technol., 34: 296-302.

23. Pires E, Brányik T. (2015). Biochemistry of beer fermentation. Springer International Publishing, AG Switzerland. https://doi.org/10.1007/978-3-319-15189-2

24. Procopio S, Krause D, Hofmann T, Becker T. (2013). Significant amino acids in aroma compound profiling during yeast fermentation analyzed by pls regression. Lebensm. Wiss. Technol. $\quad 51$ : $423-432$ http://dx.doi.org/10.1016/j.1wt.2012.11.022

25. Samara R, Hunter DM, Stobbs LW, Greig N, Lowery DT, Delury NC. (2017). Impact of Plum pox virus (PPV-D) infection on peach tree growth, productivity and bud cold hardiness. Can. J. Plant Pathol. 39: 218-228. http://dx.doi.org/10.1080/07060661.2017.1336489

26. Schiffman SS. (2007). Critical illness and changes in sensory perception. Proc. Nutr. Soc., 66: 331-345. http://dx.doi.org/10.1017/S0029665107005599

27. Singleton VL, Orthofer R, Lamuela-Raventós RM. (1998) Analysis of total phenols and other oxidation substrates and antioxidants by means of folin-ciocalteu reagent. Methods Enzymol., 299: 152-178. http://dx.doi.org/10.1016/S00766879(99)99017-1

28. Tsantili E, Shin Y, Nock JF, Watkins CB. (2010). Antioxidant concentrations during chilling injury development in peaches. Postharvest Biol. Technol., 57: 2734. http://dx.doi.org/10.1016/j.postharvbio.2010.02.002

29. Yang Z, Ma Y, Chen L, Xie R, Zhang X, Zhang B, Lu M, Wu S, Gilissen LJWJ, van Ree R, Gao Z. (2011).

Differential transcript abundance and genotypic variation of four putative allergen-encoding gene families in melting peach. Tree Genet. Genom., 7: 903-916. http://dx.doi.org/10.1007/s11295-011-0383-5 